\title{
Efficiency and mechanism of phosphorus removal by iron-organic matter associations in peatland
}

weilin Yang ( $\square$ vayneee123@outlook.com )

China University of Geosciences https://orcid.org/0000-0002-9667-7213

\section{Wu Xiang}

China University of Geosciences https://orcid.org/0000-0002-6462-0933

\section{Zhengyu Bao}

China University of Geosciences

Chunlei Huang

Zhejiang Institute of Geological Survey

\section{Ming Ma}

Zhejiang Institute, China University of Geosciences

\section{Xinzhe Lu}

Zhejiang Institute of Geological Survey

\section{Lingyang Yao}

Zhejiang Institute, China University of Geosciences

\section{Yong Wang}

Zhejiang institute of geology and mineral resource

\section{Research Article}

Keywords: phosphate, iron oxides, Fe-organic matter associations, humic substance, peatland, adsorption

Posted Date: March 1st, 2022

DOI: https://doi.org/10.21203/rs.3.rs-1335467/v1

License: (c) (1) This work is licensed under a Creative Commons Attribution 4.0 International License.

Read Full License 


\section{Abstract}

This study was carried out to evaluate the efficiency and mechanism of $P$ removal by different types of Fe-OM associations in peatlands. Humic substance (HS) and particulate organic matter (POM) were isolated from peat soils, and different types of iron-organic matter associations (Fe-HS and Fe-POM) were prepared. In addition, the natural combination of $\mathrm{Fe}^{3+}$ with peat was simulated. Then, isothermal adsorption experiments were carried out on the synthesized Fe-OM and iron-contained peat soils. All the adsorption data can be well fitted by the Langmuir adsorption model. The theoretical maximum adsorption capacity $\left(\mathrm{Q}_{\max }\right)$ of Fe-HS associations can reach $36.90 \mathrm{mg} / \mathrm{g}$, which is approximately two times higher than that of ferrihydrite $(19.23 \mathrm{mg} / \mathrm{g})$ and ten times higher than that of hematite $(3.26 \mathrm{mg} / \mathrm{g})$ and goethite $(2.08 \mathrm{mg} / \mathrm{g})$. The adsorption capacities of peat soils and POM were significantly enhanced by combinations with exogenous $\mathrm{Fe}^{3+}$. The $\mathrm{Q}_{\max }$ of the original peat and iron-contained peat were 2.83 $\mathrm{mg} / \mathrm{g}$ and $7.36 \mathrm{mg} / \mathrm{g}$, respectively, and those of the original POM and Fe-POM association were 4.31 $\mathrm{mg} / \mathrm{g}$ and $5.89 \mathrm{mg} / \mathrm{g}$, respectively. The contribution of Fe-OM associations to phosphorus removal in peatlands is much higher than that of inorganic iron oxide. In addition, exogenous $\mathrm{Fe}^{3+}$ could also participate in other phosphorus removal processes.

\section{Highlights}

1. The phosphate removal capacity of peat soils can be significantly enhanced after combining exogenous $\mathrm{Fe}^{3+}$.

2. The phosphate adsorption capacity of peat-derived organic matter and iron associations was stronger than that of inorganic iron oxides.

3. There are various phosphorus adsorption mechanisms related to iron in peatlands.

\section{Introduction}

Phosphorus $(P)$, a primary nutrient element, is essential for the growth of organisms. However, excess phosphorus can cause eutrophication and compromise the natural environment (Meinikmann et al. 2015; Dodds and Smith 2016). During the past several decades, many studies have been conducted to determine the fate of $\mathrm{P}$ in wetland systems (Dierberg et al. 2020; Ni et al. 2020; Song et al. 2007). In wetlands, exogenous phosphorus can be removed by microbial processes, plant uptake, sedimentation and precipitation, and adsorption by the mineral surfaces (Wu et al. 2019; Liu et al. 2000; Haritash et al. 2017; Spangler et al. 2019; Yuhui et al. 2020; Ghodsi et al. 2020; Kubicki et al. 2012). Due to the complexity of wetland system, the capacity and efficiency of various $\mathrm{P}$ removal processes have not been thoroughly studied.

Peatland is a terrestrial wetland ecosystem where the production of organic matter exceeds decomposition. Thus, approximately one-third of the total soil carbon in peatlands (Page et al. 2010). HS represents a large portion of natural OM in soils and typically consists of humic acid (HA), fulvic acid (FA) 
and humin (Newcomb 2015; Koivula and Hänninen 2001). Due to its complex structural characteristics and functional groups, HS has a strong adsorption complexation capacity that can react with inorganic or organic pollutants (Wang et al. 2020; Piccolo et al. 2021). Non-humic substances are composed of more labile organic matter (LOM) that include free particulate organic matter (free-POM) and occluded particulate organic matter (occluded-POM) (Rodionov et al. 2000; Six et al. 2008; Six et al. 2002). Despite the fact that particulate organic matter (POM) comprises a relatively small fraction of SOM $(10-25 \%$ of soil $\mathrm{C}$ ), it is a critical constituent in soil carbon cycling because of the rapid response to the changes in soil properties (Gregorich et al. 2006; Beare and Gregorich 2007; Baldock et al. 2018).

Iron is one of the most abundant transition metal elements in peatland. Due to the difference of geological environment and water supply mode, the content of iron in peatland varies greatly. Zak et al. (2019) investigated 11 different peatlands situated along freshwater sources in postglacial landscape of northwest Germany and northwest Poland, the results showed that the iron contents varied from $0.75 \mathrm{mg} / \mathrm{kg}$ to $22 \mathrm{mg} / \mathrm{g}$. Zhao et al. (2019) measured the content of iron in peat covered with different vegetation in Dajiu Lake peatland, the total Fe in peat soils showed a range of $9.55-37.5 \mathrm{mg} / \mathrm{g}$ which indicated a very Fe-rich environment. Though Fe concentration in peat are typically lower than mineral soils $(10-300 \mathrm{mg} / \mathrm{g}$ ) (Bohn et al. 2014), its active chemical properties still have an important impact on soil elements and material cycle.

Characterized as ubiquitous redox interfaces with large amounts of organic matter and active iron, peatlands provide favorable interfaces for the formation of iron-organic matter (Fe-OM) associations (Zhao et al. 2019; Zhao et al. 2020; Curtinrich et al. 2021; Zhao et al. 2021), which may occur through coordination complexation, ion exchange and cation bridges (Fu and Quan 2006; Mikutta et al. 2007; Elfarissi and Pefferkorn 2000). Zhao et al. (2019) investigated the contents of Fe-bound organic and organic Fe in DaJiu Lake peatland, the results showed that they accounted for $7.6-17.3 \%$ of total organic matter content and $13.54-53.65 \%$ of total iron content, respectively. Fe concentration ranging from 500 to $\sim 2,500 \mu \mathrm{g} / \mathrm{g}$ and up to $300 \mu \mathrm{g} / \mathrm{g}$ were reported for bulk peat and corresponding humic acids (HA), respectively (Zaccone et al. 2007). These research indicate the close relationship between iron and organic matter in peatland.

According to the combination mode of iron and organic matter, Fe-OM associations could be divided into two types, coprecipitated Fe-OM and OM-adsorbed to iron oxides (Kleber et al. 2015). Both of them have remarkable anti-biodegradation properties, which allows for their long-term stability in soil (Chen et al. 2016; Eusterhues et al. 2014; Curti et al. 2021). Organic matter adsorption can change the surface properties of iron oxide (Ohno and Kubicki 2020; Zhou et al. 2014; Kaiser and Guggenberger 2003), while coprecipitation can increase the disorder degree and electromagnetism of iron mineral structures (Thomasarrigo et al. 2018; Hayes et al. 2009). These changes in iron oxide properties would have various influences on the adsorption and fixation capacity. For example, OM may compete with phosphate for adsorption sites, which could weaken the phosphate adsorption capacity of Fe-OM complexes by the dissolution of iron oxides, creation of new adsorption sites, and retardation of iron oxide crystal growth (Deng et al. 2019; Wang et al. 2015a; Cornell and Schwertmann 1979; Borggaard et al. 2005). However, 
several studies proposed that HS does not significantly affect the adsorption behavior of iron oxide (Borggaard et al. 2006; Weng et al. 2009). Khouri et al. (1995) suggested that the inhibition of phosphate adsorption by OM was temporary, while Chen et al. (2018) found that coprecipitates of ferrihydrite and $\mathrm{OM}$ yield $\mathrm{P}$ sorption properties nearly equivalent to that of pure ferrihydrite.

Although extensive studies confirm that iron oxides in the soil matrix play a significant role in $\mathrm{P}$ adsorption and fixation (Dorau et al. 2019; Koopmans et al. 2019; Fan et al. 2021), few studies have been conducted to evaluate the efficiency and mechanism of $\mathrm{P}$ removal by Fe-OM associations in peatlands. Due to the complexity of Fe-OM associations, further clarification of the $\mathrm{P}$ removal processes by Fe-OM associations will assist in the evaluation of the $P$ removal capacity of peatlands. Therefore, the main purpose of this study is to examine the efficiency and mechanism of phosphate removal by the different types of Fe-OM associations in peatlands in an effort to further understand the contribution of $\mathrm{Fe}-\mathrm{OM}$ associations to the phosphate removal capacity of peatlands.

\section{Methods And Materials}

\subsection{Chemicals}

Superlite XAD-8 Macroporous Resin (Sigma-Aldrich Co. LLC, USA) was used to refine humic substances. All other reagents were analytically pure and purchased from Sinopharm Chemical Reagent Co., Ltd. (Shanghai, China). Deionized water (15.0 M $\Omega$, obtained through an Elix Advantage water purification system, Merck Millipore Corp., Darmstadt, Germany) was used for reagent preparation and experiments.

\subsection{Preparation of peat soil}

Peat soil samples were collected from Jinchuan peatland located in Jinchuan Town, Huinan County, Jilin Province $\left(42^{\circ} 20^{\prime} 56^{\prime \prime} \mathrm{N}, 126^{\circ} 22^{\prime} 51^{\prime \prime} \mathrm{E}\right)$. The collected surface peat soils were freeze-dried by a freeze dryer (LGJ-10, Beijing Songyuanhuaxing Technology Develop Co., Ltd.) and then sieved using a 40-mesh (400 $\mathrm{mm}$ ) sieve. Total organic carbon (TOC) in dried samples were measured by a TOC analyzer (Elementar Vario TOC, Germany). The contents of iron-bound organic carbon were analyzed through the modified method of DCB (Sodium Dithionite-Citrate-Bicarbonate) (Lalonde et al. 2012; Wang et al. 2017).

\subsection{Extraction and purification of HA and FA}

HA and FA were isolated from a peat soil sample according to the method recommended by the International Humic Substances Society (IHSS) (Swift 1996). Briefly, $50.0 \mathrm{~g}$ of peat soil was added to a $500 \mathrm{~mL}$ conical flask with $500 \mathrm{~mL}$ of $0.1 \mathrm{~mol} / \mathrm{L} \mathrm{HCl}$, and the $\mathrm{pH}$ of the suspension was immediately adjusted to 1.0-2.0 using $1 \mathrm{~mol} / \mathrm{L} \mathrm{HCl}$ under a $\mathrm{N}_{2}$ atmosphere. After the suspension was equilibrated for $1 \mathrm{~h}$, the supernatant containing FA was separated from the solid residue. FA was purified using XAD-8 resin and cation exchange resin and then freeze-dried and stored in the absence of light.

The soil residue, which contained the HA fraction, was neutralized to $\mathrm{pH} 7.0$ with $1 \mathrm{~mol} / \mathrm{L} \mathrm{NaOH}$, followed by $0.1 \mathrm{~mol} / \mathrm{L} \mathrm{NaOH}$ additions to give a final extractant: soil ratio of 10:1. The suspension remained 
quiescent for $12 \mathrm{~h}$ under $\mathrm{N}_{2}$. The residue was separated from the suspension and dissolved using the smallest volume of $0.1 \mathrm{~mol} / \mathrm{L} \mathrm{KOH}$, and then, solid $\mathrm{KOH}$ was added to make the concentration of $\mathrm{K}^{+}$reach $0.3 \mathrm{~mol} / \mathrm{L}$. After 4 hours of equilibration, the suspension was centrifuged for $10 \mathrm{~min}$ at $3000 \mathrm{rpm}$ and the supernatant decanted. The $\mathrm{pH}$ of the supernatant was then adjusted to $1.0-2.0$ using $6 \mathrm{~mol} / \mathrm{L} \mathrm{HCl}$ under $\mathrm{N}_{2}$ to precipitate $\mathrm{HA}$, which was dissolved with $0.1 \mathrm{~mol} / \mathrm{L} \mathrm{HCl}$ and $0.3 \mathrm{~mol} / \mathrm{L} \mathrm{HF}$ solution in a $50 \mathrm{~mL}$ centrifuge tube and shaken overnight. The derived HA were purified in a 1000 Dalton dialysis bag with deionized water until the conductivity of the effluent was less than $20 \mu \mathrm{s} / \mathrm{cm}$ (DDBJ-350, INESA Scientific Instrument Co., Ltd., Shanghai, China). The salt-free HA concentrate were freeze-dried and stored in the absence of light.

Fourier transform infrared (FTIR) spectroscopy of HA and FA was performed to compare the differences in functional groups using an FTIR spectrometer (Nicolet iS50, Thermo Fisher Scientific). The concentrations of hydroxy and carboxyl groups were determined by the method of Wen (1984) using a potentiometric titrator (T860, Hanon Instruments Co., Ltd., Jinan, China).

\subsection{Separation of particulate organic matter}

Particulate organic matter (POM) was isolated from a peat soil sample following a procedure described by Elliot and Cambardella (1991). Briefly, $50.0 \mathrm{~g}$ of freeze-dried peat sample was dispersed in $100 \mathrm{~mL}$ of $\mathrm{Na}_{6}\left(\mathrm{PO}_{3}\right)_{6}$ (sodium hexametaphosphate solution, $5 \mathrm{~g} / \mathrm{L}$ ) and shaken on a reciprocal shaker for $18 \mathrm{~h}$. The soil suspension was then passed through a $53 \mu \mathrm{m}$ sieve. The material remaining on the sieve was rinsed thoroughly with deionized water, freeze-dried and stored as the POM sample.

\subsection{Synthesis of iron oxides}

Ferrihydrite $\left(\mathrm{Fe}_{2} \mathrm{O}_{3} \cdot 0.5 \mathrm{H}_{2} \mathrm{O}\right)$, goethite $(\mathrm{FeO}(\mathrm{OH}))$, and hematite $\left(\mathrm{Fe}_{2} \mathrm{O}_{3}\right)$ were synthesized according to the method of Schwertmann and Cornell (1992).

Ferrihydrite was synthesized by hydrolysis of $500 \mathrm{~mL}$ of $0.2 \mathrm{~mol} / \mathrm{L}$ ferric nitrate nonahydrate $\left(\mathrm{Fe}\left(\mathrm{NO}_{3}\right)_{3} \cdot 9 \mathrm{H}_{2} \mathrm{O}\right)$ solution with $330 \mathrm{~mL}$ of $1 \mathrm{~mol} / \mathrm{L} \mathrm{KOH}$ solution in a $1 \mathrm{~L}$ beaker at a pH between 7.0-8.0. Goethite was synthesized by hydrolysis of $50 \mathrm{~mL}$ of a $1 \mathrm{~mol} / \mathrm{L} \mathrm{Fe}\left(\mathrm{NO}_{3}\right)_{3} \cdot 9 \mathrm{H}_{2} \mathrm{O}$ solution with $90 \mathrm{~mL}$ of 5 $\mathrm{mol} / \mathrm{L} \mathrm{NaOH}$ solution in a $1 \mathrm{~L}$ polypropylene bottle, resulting in the rapid precipitation of ferrihydrite. The resulting suspension was diluted to $1 \mathrm{~L}$ with deionized water and aged for $60 \mathrm{~h}$ at $70^{\circ} \mathrm{C}$, forming a yellow precipitate. Hematite was synthesized by adding $40.0 \mathrm{~g}$ of $\mathrm{Fe}\left(\mathrm{NO}_{3}\right)_{3} \cdot 9 \mathrm{H}_{2} \mathrm{O}$ to $500 \mathrm{~mL}$ of deionized water, $300 \mathrm{~mL}$ of $1 \mathrm{~mol} / \mathrm{L} \mathrm{KOH}$ solution and $50 \mathrm{~mL}$ of $1 \mathrm{~mol} / \mathrm{L} \mathrm{NaHCO}_{3}$ solution in a $1 \mathrm{~L}$ polypropylene bottle. All the above solutions were heated to $90^{\circ} \mathrm{C}$ before mixing. The suspension was then aged for $48 \mathrm{~h}$ at $90^{\circ} \mathrm{C}$, forming a red precipitate.

All the precipitates were washed with deionized water until the conductivity of effluent was less than 20 $\mu \mathrm{s} / \mathrm{cm}$. Finally, the precipitates were freeze-dried for experimental use. Each of the three inorganic iron oxides were tested by SEM (Scanning Electronic Microscopy, HITACHI SU8010, Hitachi Instruments Co., 
Ltd.) and XRD (X-ray diffraction, Bruker D8 Advance, BRUKER AXS GMBH) to determine their crystal structural morphology and species.

\subsection{Synthesis of different Fe-organic matter associations}

Fe-HS (Fe-humic substance associations) with different ratios of iron and HS were synthesized as follows: $100 \mathrm{~mL}$ of $0.5 \mathrm{~mol} / \mathrm{L} \mathrm{Fe}\left(\mathrm{NO}_{3}\right)_{3}$ solution was mixed with $5 \mathrm{~mL}$ of $\mathrm{FA}$ (Association A), $25 \mathrm{~mL}$ of $\mathrm{FA}$ (Association B), $5 \mathrm{~mL}$ of $\mathrm{HA}$ (Association $\mathrm{C}$ ) and $25 \mathrm{~mL}$ of $\mathrm{HA}$ (Association $\mathrm{D}$ ), and the $\mathrm{pH}$ of mixtures were titrated to $7.5 \pm 0.1$ using $1 \mathrm{~mol} / \mathrm{L} \mathrm{NaOH}$ and incubated for $1 \mathrm{~h}$.

Fe-POM associations were synthesized by adding $15 \mathrm{~mL}$ of different concentrations $(0,5,10,20,30,50$ $\mathrm{mg} / \mathrm{L})$ of $\mathrm{Fe}\left(\mathrm{NO}_{3}\right)_{3}$ solutions into POM samples, and then, the mixtures were shaken at $20^{\circ} \mathrm{C}$ for $48 \mathrm{~h}$ to simulate the integration process of iron and POM in a natural environment.

Fe-HS associations were tested by XRD and SEM to determine their crystal structural morphology and species. The contents of $\mathrm{C}$ and $\mathrm{Fe}$ in Fe-HS associations were analyzed by TOC and atomic absorption spectrometry (AAS) (TAS-990, Beijing Purkinje General Instrument Co., Ltd) by dissolving associations in $6 \mathrm{~mol} / \mathrm{L} \mathrm{HCl}$.

\subsection{Simulating the natural combination of $\mathrm{Fe}^{3+}$ and bulk peat}

Fifteen milliliters of different concentrations $(0,5,10,20,30,50 \mathrm{mg} / \mathrm{L})$ of $\mathrm{Fe}\left(\mathrm{NO}_{3}\right)_{3}$ solutions were added to $2.0 \mathrm{~g}$ of peat soil in $50 \mathrm{~mL}$ conical flasks. The simulated transformation process of iron under natural conditions was accelerated by shaking the flasks at $25^{\circ} \mathrm{C}$ for 48 hours. $30 \mathrm{ml}$ of deionized water was added to the mixture, and the supernatant and sediment were then separated by centrifugation. The concentrations of iron and TOC in the supernatant were measured, and the content of $\mathrm{Fe}^{3+}$ complexed by peat soils and the organic carbon released from peat were calculated by the differences between the Fe ${ }^{3+}$ concentration before and after the combination process.

\subsection{Isothermal adsorption of phosphate}

Phosphate solutions of various $P$ concentrations ranging from 0-100 mg/L were obtained by adding potassium dihydrogen phosphate $\left(\mathrm{KH}_{2} \mathrm{PO}_{4}\right)$ into an aqueous solution containing $0.1 \mathrm{mmol} / \mathrm{L} \mathrm{CaCl}$ solution as the electrolyte. The $\mathrm{pH}$ values of all phosphate solutions were titrated to $4.5 \pm 0.1$ using 0.1 $\mathrm{mmol} / \mathrm{L} \mathrm{NaOH} / \mathrm{HNO}_{3}$ solutions.

The adsorbents (inorganic iron oxides, Fe-OM associations, original peat soils and iron-complexed bulk peat soils) were equilibrated in solutions containing different $\mathrm{P}$ concentrations in $10 \mathrm{~mL}$ centrifuge tubes and then shaken on a reciprocal shaker for $24 \mathrm{~h}$ at $20^{\circ} \mathrm{C}$. After adsorption, all samples were centrifuged at $8000 \mathrm{rpm}$ for $10 \mathrm{~min}$, and the supernatant solutions were filtered through $0.45 \mu \mathrm{m}$ cellulose acetate membrane filters. 
The concentrations of $\mathrm{P}$ in the filtrate was determined in $48 \mathrm{~h}$ with the molybdate blue colorimetric method (Murphy and Riley 1962) using an ultraviolet-visible spectrophotometer at a wavelength of 700 $\mathrm{nm}$. Each adsorption experiment was performed in duplicate to confirm the reproducibility.

\subsection{Statistical analysis}

The adsorbed phosphate amount was calculated by the change in solution concentration through mass balance. The Langmuir isotherm model was used to analyze the phosphate adsorption process. The model assumes monolayer adsorption onto the surface with a finite number of identical sites and is expressed by the following equation:

$$
Q=\frac{Q \max K C}{1+K C}
$$

In its linear form, the Langmuir equation can be described as

$$
\frac{C}{Q}=\frac{C}{Q \max }+\frac{1}{K Q \max }
$$

where $C$ represents the concentration of phosphate solution at equilibrium $(\mathrm{mg} / \mathrm{L}), \mathrm{Q}$ represents the amount of phosphate adsorbed per unit mass at equilibrium, $Q_{\max }$ is the maximum theoretical amount of phosphate adsorbed per unit mass. $\mathrm{K}(\mathrm{L} / \mathrm{mg})$ is defined as the ratio of adsorption rate constant to desorption rate constant, and represents the Langmuir equilibrium constant related to the affinity between the phosphate and the sorbent.

\section{Results And Discussion}

\section{1 characteristics of materials}

The $\mathrm{pH}$ value of soil samples is between 5.29-5.8, with an average value of 5.47. The content of total organic carbon in the peat soil samples ranged from $19.73-44.0 \%$, and the content of Fe-bound organic carbon ranged from $4.1-10.98 \%$. Overall, Fe-bound organic carbon content accounted for $20.78 \%-24.95 \%$ of the total organic carbon content.

The morphologies of ferrihydrite, goethite, hematite and Fe-HS associations were characterized by SEM. As shown in Fig. 1, ferrihydrite has no clear crystal structure, suggesting an amorphous phase. A long column structure for synthetic goethite is observed, indicating that goethite was successfully prepared. Hematite has a clear crystal form of granular type. The four Fe-HS associations show the same morphologies of amorphous characteristics as ferrihydrite under the SEM.

XRD patterns of iron oxides are shown in Fig. 2a. The synthesized ferrihydrite has no characteristic peaks in the XRD spectrum, suggesting an amorphous mineral. Goethite and hematite have clear characteristic peaks, marked as triangle mark and square mark. Combined with the standard database JCPDS (The Joint Committee on Powder Diffraction Standard), these peaks are identified as goethite (PDF: 29-0713) 
and hematite (PDF: 72-0469). Figure $2 \mathrm{~b}$ shows the XRD patterns of four Fe-HS associations, two broad peaks at degree 21 and 35 were found in all samples. Thus, these four Fe-HS associations can be regarded as two-line ferrihydrite.

From the XRD and SEM patterns, it was verified that the synthesized inorganic iron oxides and four Fe-HS associations were of high purity, and met the requirements of the experiment.

The Fourier transform infrared (FT-IR) spectra of HA and FA are depicted in Fig. 3. The absorption peaks at $3434 \mathrm{~cm}^{-1}$ correspond to $-\mathrm{OH}$ vibration elongation in alcohols or phenolic compounds (Mazzetti and Thistlethwaite 2002). The absorption peaks at $2925 \mathrm{~cm}^{-1}$ are assigned to the $-\mathrm{OH}$ vibration elongation in the carboxylic acids. The two spectra patterns have similar peaks below $2000 \mathrm{~cm}^{-1}$. However, FA has an additional absorption peak at $1723 \mathrm{~cm}^{-1}$ compared with $\mathrm{HA}$, which is the characteristic absorption peak of $\mathrm{C}=\mathrm{O}$ vibration elongation.

The contents of hydroxyl and carboxyl group in HA and FA were measured by potentiometric titration. The content of hydroxyl and carboxyl group in $\mathrm{HA}$ is $5.14 \mathrm{mmol} / \mathrm{L}$ and $2.34 \mathrm{mmol} / \mathrm{L}$ respectively, while that in FA is $8.02 \mathrm{mmol} / \mathrm{L}$ and $6.25 \mathrm{mmol} / \mathrm{L}$ respectively. By comparison, the contents of carboxyl and hydroxyl group in FA are both higher than those in HA, which is consistent with previous research proposing that FA has more oxygen-containing functional groups than HA (Li et al. 2019).

The contents of carbon and iron in the four Fe-HS associations were measured and the molar ratio was calculated and listed in Table 1. In the synthesis process of association B and D, more HA and FA is added, so their carbon content are obviously higher than that of $A$ and $C$. There was no significant difference in iron content among the four associations, so the molar ratio of $\mathrm{Fe} / \mathrm{C}$ in association $\mathrm{A}$ and $\mathrm{C}$ are higher than $B$ and $D$.

Table 1

Fitting parameters of Langmuir equation describing phosphate adsorption onto iron oxides and Fe-HS associations

\begin{tabular}{|lllll|}
\hline adsorbents & & $\mathbf{R}^{2}$ for Langmuir & $\mathbf{Q}_{\max }(\mathrm{mg} / \mathrm{g})$ & $\mathrm{K}(\mathrm{L} / \mathrm{mg})$ \\
\hline Ferrihydrite & 0.9791 & 19.230 & 0.082 \\
\hline Hematite & & 0.9976 & 3.258 & 0.321 \\
Goethite & & 0.9934 & 2.080 & 1.181 \\
& Fe/C (molar ratio) & & & \\
\hline Association A & 11.84 & 0.9525 & 26.041 & 0.106 \\
\hline Association B & 4.99 & 0.9371 & 31.847 & 0.042 \\
\hline Association C & 13.09 & 0.9474 & 33.557 & 0.051 \\
\hline Association D & 4.85 & 0.9346 & 36.900 & 0.039 \\
\hline
\end{tabular}




\subsection{Isothermal adsorption of phosphate by iron oxides and Fe-HS associations}

Isothermal phosphate adsorption onto inorganic iron oxides (goethite, hematite and ferrihydrite) and four types of Fe-HS associations are depicted in Fig. 4, which shows that the adsorbed phosphate increased with the initial phosphate concentration. However, when the concentration of initial phosphate was greater than $20 \mathrm{mg} / \mathrm{L}$, the amount of phosphate adsorbed leveled off for goethite and hematite. A Langmuir model was applied to fit the adsorption data, and the fitting parameters are listed in Table 1. A higher correlation coefficient value $\left(R^{2}>0.937\right)$ indicates that the Langmuir model adequately fits to describe the isothermal adsorption.

The fitting parameters are listed in Table 1. The $Q_{\max }$ of ferrihydrite, hematite and goethite are 19.23 $\mathrm{mg} / \mathrm{g}, 3.25 \mathrm{mg} / \mathrm{g}$ and $2.08 \mathrm{mg} / \mathrm{g}$, respectively. The adsorption capacity of ferrihydrite is much higher than that of hematite and goethite, which is consistent with previous studies (Wang et al. 2013; Shao et al. 2006; Liu et al. 2021). Liu et al. (2021) found that electrostatic attraction was the predominant coadsorption mechanism for phosphate ions on goethite, while surface precipitation was the most significant on ferrihydrite. According to Schwertmann and Cornell (1992), ferrihydrite is an amorphous oxide with the highest degree of activity among these three iron oxides and larger specific surface area, so its adsorption capacity is much greater than that of goethite and hematite with higher crystallinity.

In addition, the $\mathrm{Q}_{\max }$ values (Table 1) indicate that the Fe-HS associations have a higher capacity for phosphate adsorption than inorganic iron oxides, and the $\mathrm{Q}_{\max }$ of Fe-HS associations are all above 26.04 $\mathrm{mg} / \mathrm{g}$, which are approximately one order of magnitude larger than those of hematite and goethite. This finding indicates that the incorporated HS result in an enhanced binding affinity of phosphate onto Fe-HS association, likely beacuse HS incorporated into Fe-HS would disturb the structure of ferrihydrite and increases its disorder degree, resulting in a rougher surface and larger specific surface area of the precipitate (Laird 2001). In addition, organic ligands such as HS would inhibit Fe(II)-catalyzed ferrihydrite mineral transformations and the formation of crystalline secondary mineral phases compared to a pure ferrihydrite (Thomasarrigo et al. 2018, 2019), giving it high site density and large surface area, ultimately leading to a higher adsorption capacity of Fe-HS associations. Contrary to our results, Wang et al. (2015b) found that the coprecipitated ferrihydrite-HA associations adsorb less phosphate than pure ferrihydrite, they speculated that HA could occupy the specific adsorption sites and decrease the binding sites for phosphate adsorption. Violante and Huang (1989) also proposed that HA could develop a negative charge through the ionization of functional groups, decreasing the electrostatic interaction between phosphate and ferrihydrite-HA associations and thus weakening the adsorption capacity. Another possible explanation is that HS is indirectly related to the phosphate adsorption, the formation of complex with iron or aluminum is the factor that directly influence the adsorption capacity of soil matrix (López et al. 1996; Bruland and Richardson 2006). 
The Higher Langmuir equilibrium constant $\mathrm{K}(\mathrm{L} / \mathrm{mg})$ represents the faster adsorption. From Table 1, although the adsorption rate of goethite among these three iron oxides is the highest, $Q_{\max }$ value is the lowest, and the opposite is true for ferrihydrite. However, $\mathrm{Q}_{\max }$ is a more important parameter relative to $\mathrm{K}$ in our study, because the adsorption and removal of phosphorus by peat soil is a long-term process.

It is also noted that Fe-HA associations ( $C$ and $D$ ) have higher $\mathrm{Q}_{\max }$ than Fe-FA associations ( $A$ and $B$ ) (Table 1), which may be due to the difference in functional group composition between HA and FA. HA is higher in molecular mass and contains fewer oxygen-containing functional groups than FA. Thus, FA has more charge that results in a more compact structure of associations than HA. It was also found that regardless of $\mathrm{HA}-\mathrm{Fe}$ or $\mathrm{FA}-\mathrm{Fe}$, associations with high organic carbon content (B and $\mathrm{D})$ have better adsorption capacity than those with low organic carbon content ( $A$ and $B$ ). These results verified that organic matter complexing with iron can promote the phosphate adsorption capacity of iron oxides.

\subsection{Isothermal adsorption of phosphate by POM and Fe- POM associations}

Although POM comprises a relatively small fraction of SOM, its role in soil cannot be ignored due to its high activity. The adsorption results of extracted POM and Fe-POM associations are depicted in Fig. 5, which shows that when the initial phosphate concentration was less than $20 \mathrm{mg} / \mathrm{L}$, the amount of phosphate adsorbed on Fe-POM associations rapidly increased. However, when the initial phosphate concentration was greater than $20 \mathrm{mg} / \mathrm{L}$, the adsorbed phosphate increased more slowly. The estimated model parameters with the correlation coefficient $\left(R^{2}\right)$ for the Langmuir equation are given in Table 2 .

Table 2

Fitting parameters of Langmuir equation describing phosphate adsorption onto Fe-POM associations

\begin{tabular}{|lllll|}
\hline $\begin{array}{l}\text { Concentration of Fe } \\
\text { into POM (mmol/L) }\end{array}$ & $\begin{array}{l}\text { Content of Fe } \mathrm{Fe}^{3+} \text { complexed } \\
\text { by POM (mg) }\end{array}$ & $\mathrm{R}^{\mathbf{2}}$ & $\begin{array}{l}\mathbf{Q}_{\max } \\
(\mathbf{m g} / \mathbf{g})\end{array}$ & $\mathrm{K}$ \\
\hline 0 & 0 & 0.9940 & 4.310 & 0.117 \\
\hline 5 & 4.280 & 0.9844 & 4.761 & 0.081 \\
\hline 10 & 8.435 & 0.9422 & 4.508 & 0.086 \\
\hline 20 & 17.363 & 0.9893 & 4.863 & 0.155 \\
\hline 30 & 21.083 & 0.9769 & 5.144 & 0.153 \\
\hline 50 & 39.225 & 0.9960 & 5.885 & 0.254 \\
\hline
\end{tabular}

In terms of the $\mathrm{R}^{2}$ values listed in Table 2, the isotherm adsorption of Fe-POM can be satisfactorily described by the Langmuir model. Compared with the $\mathrm{Q}_{\max }$ of pure POM without $\mathrm{Fe}^{3+}$ (control group), the association of iron and POM improves the adsorption capacity of POM. There is also a tendency for the adsorption capacity of Fe-POM associations to be enhanced with the increase in complexed $\mathrm{Fe}^{3+}$ content, suggesting that POM and Fe-POM associations may be another important contributor to the removal of 
phosphate in peat soils. In addition to the increase of $\mathrm{Q}_{\max }$, the $\mathrm{K}$ value of Fe-POM also increased to a certain extent, indicating that the adsorption rate of phosphate also increased. This result is similar to that of Fe-HS associations, that is, the higher the iron content is, the faster the adsorption rate is.

\subsection{Isothermal adsorption of phosphate by original peat and Fe-complexed peat soils.}

To further evaluate the effect of iron-bound organic matter on phosphate adsorption in peat soils, we carried out experiments on some original soil. Different concentration of exogenous $\mathrm{Fe}^{3+}(0,5,10,20,30$, $50 \mathrm{mmol} / \mathrm{L}$ ) solutions were added into the peat soils, and incubated for $48 \mathrm{~h}$. The incubated soils were measured for the content of DOC as well as the amount of $\mathrm{Fe}^{3+}$ complexed. The measurement data showed that DOC in the soil had already been completely consumed when the concentration of $\mathrm{Fe}^{3+}$ was only $5 \mathrm{mmol} / \mathrm{L}$, and the content of soil-complexed $\mathrm{Fe}^{3+}$ increased with the increase of exogenous $\mathrm{Fe}^{3+}$ concentration (Table 3 ). This result suggests that DOC in the peat soil was indeed involved in the complexing with $\mathrm{Fe}^{3+}$.

Table 3

Fitting parameters of Langmuir equation describing phosphate adsorption onto peat soils

\begin{tabular}{|lllll|}
\hline $\begin{array}{l}\text { Concentration of } \mathrm{Fe}^{3+} \text { solution added } \\
\text { into peat soil (mmol/L) }\end{array}$ & $\begin{array}{l}\text { Amount of } \mathrm{Fe}^{3+} \text { complexed } \\
\text { by peat soils }(\mathbf{m g})\end{array}$ & $\mathbf{R}^{\mathbf{2}}$ & $\begin{array}{l}\mathbf{Q}_{\max } \\
(\mathbf{m g} / \mathbf{g})\end{array}$ & $\mathrm{K}$ \\
\hline 0 & 0 & 0.9871 & 2.832 & 0.181 \\
\hline 5 & 3.436 & 0.9697 & 3.882 & 0.219 \\
\hline 10 & 7.636 & 0.9628 & 4.640 & 0.096 \\
\hline 20 & 14.675 & 0.9826 & 5.737 & 0.141 \\
\hline 30 & 21.319 & 0.9880 & 7.087 & 0.060 \\
\hline 50 & 32.449 & 0.9887 & 7.364 & 0.113 \\
\hline
\end{tabular}

The results of isothetmal adsorption experiment carried out on these iron-containing peat soils were depicted in Fig. 6. The amount of adsorbed phosphate rapidly increased when the initial phosphate concentration was less than $20 \mathrm{mg} / \mathrm{L}$. While the concentration of initial phosphate exceeded $20 \mathrm{mg} / \mathrm{L}$, the amount of $\mathrm{P}$ adsorbed per unit sorbent decreased significant.

The fitting parameters in Table 3 indicate that the experimental data were satisfactorily described by the Langmuir model $\left(R^{2}\right.$ values $\left.>0.962\right)$. In addition, the $Q_{\max }$ values increased with concentrations of complexed $\mathrm{Fe}^{3+}$, confirming that the adsorption capacity of peat soil is significantly enhanced by complexing with exogenous $\mathrm{Fe}^{3+}$. It has been very well documented that the phosphate adsorption capacity of soils has an excellent positive correlation with soil Fe content, which is mainly attributed to the presence of various iron minerals in soils. Axt and Walbridge (1999) found that there was a linear relationship between the amount of phosphate adsorbed and the contents of amorphous and crystalline 
iron oxides in soils. Other studies also have demonstrated amorphous Fe oxides are responsible for the majority of P adsorption in soils (Arai and Livi 2013; Vandervoort and Arai 2011).

It can be inferred that iron and organic matter in peat soils play pivotal roles in the adsorption of phosphate under oxic conditions. Moreover, the interaction of iron and organic matter greatly promotes the phosphate adsorption. Phosphate and organic matter are normally negatively charged at $\mathrm{pH}$ values in natural environments, so phosphate is unlikely to combine with organic matter directly through electrostatic binding (Newcomb 2015). However, HS have an affinity to complex with aluminum, iron and other metal ions, which allows phosphate to combine with organic matter through the bridging of aluminum and iron ions (Mikutta et al. 2006). Bruland and Richardson (2006) reported a significant positive correlation between the phosphate adsorption capacity of soil and the content of organic matter, and Kang et al. (2009) considered that this relationship was mainly attributed to free iron or aluminum. Organic matter in peat soil can release hydrogen ions, thereby protonate the surfaces of minerals and promote the phosphate adsorption capacity (Gerke and Hermann 1992). The insoluble organic matter in the soil can also chelate iron and aluminum, which increases the adsorption amount of soil phosphate (Parfitt 1982). Nur and Bates (1979) found that aluminum and iron phosphate fraction predominate under acid condition in lake sediment, and the sediment contained more iron bound phosphate than aluminum bound phosphate at the lower $\mathrm{pH}$ values.

To further estimate the removal efficiency of phosphorus by Fe-OM associations in iron-containing peat, we assume that all exogenous $\mathrm{Fe}^{3+}$ transformed into inorganic iron oxides (Ferrihydrite and Hematite), and their contributions to soil phosphorus removal capacity were calculated respectively (Fig. 7). The result indicates that the actual $Q_{\max }$ of peat soil sharply increase after adding exogenous $\mathrm{Fe}^{3+}$, but the inorganic oxides still can not fully explain the actual removal. Morris and Hesterberg (2012) suggested that iron in peat occurred either exclusively as mononuclear Fe-organic complexes or a mixture of Feorganic complexes and polynuclear Fe species. Most Fe in peatlands is in strongly bound chelate form, and only approximately $4-5 \%$ of the total Fe in peatlands is in water-soluble and exchangable forms (Yonebayashi 2006). Accordingly, most exogenous $\mathrm{Fe}^{3+}$ would not be transformed into pure inorganic iron oxides in peat soil, but combined with organic matter to form Fe-OM associations. Therefore, the increased phosphorus removal capacity after the addition of exogenous $\mathrm{Fe}^{3+}$ to peat soils should be largely attributed to the formation of Fe-OM associations.

However, the synthesized Fe-OM associations in this study still could not fully represent the native associations of iron and organic matter in peat soil, because the $\mathrm{Fe} / \mathrm{C}$ ratio in the synthesized Fe-HS associations is higher than that in the actual peat soil $(0.08-5.026)$. It is likely that the natural Fe-HS associations in peat soil would have better adsorption capacity than the lab synthesized Fe-HS associations. Beside of these, other coexisting removal mechanisms may also include: 1) Some of the exogenous $\mathrm{Fe}^{3+}$ might be transformed into iron oxide and coated on the surface of clay minerals, and $\mathrm{OH}^{-}, \mathrm{OH}_{2}$ and $\mathrm{OH}_{3}{ }^{+}$groups of iron oxide would allow clay minerals to have many surface groups that can exchange and coordinate with inorganic and organic ions (Tan et al. 2007; Green-Pedersen and Pind 
2000). 2) Exogenous $\mathrm{Fe}^{3+}$ could complex with low molecular weight organic acids (LMWOA) such as oxalic acid, malic acid and citric acid, thus weakening the inhibition of phosphate adsorption by LMWOA and increasing phosphorus adsorption by peat soil. 3) When iron and aluminum form composite oxides, the adsorption capacity of composite oxides for phosphorus is stronger than that of iron oxides or aluminum oxides separately (Yang et al. 2009a; Li et al. 2008). In addition, Mn and Si may affect the adsorption capacity of phosphate (Yang et al. 2009b; Cismasu et al. 2011).

In conclusion, with the increase in peat combined with exogenous $\mathrm{Fe}^{3+}$, the removal efficiency of phosphorus significantly increased. In addition to the contribution of Fe-organic association adsorption, there are other phosphorus removal mechanisms related to iron in peat, which should be studied further.

\section{Conclusions}

In this study, isothermal phosphate adsorption experiments were carried out to investigate the phosphate adsorption capacity of peat soils, inorganic iron oxides (ferrihydrite, goethite and hematite) and Feorganic associations (Fe-HS, Fe-POM). The theoretical maximum adsorption capacity $\left(\mathrm{Q}_{\max }\right)$ of Fe-HS associations can be up to $36.90 \mathrm{mg} / \mathrm{g}$, which is approximately two times higher than that of ferrihydrite $(19.23 \mathrm{mg} / \mathrm{g})$ and approximately ten times higher than that of hematite $(3.26 \mathrm{mg} / \mathrm{g})$ and goethite $(2.08$ $\mathrm{mg} / \mathrm{g}$ ). The adsorption capacities of peat soils and POM were significantly enhanced by the combination with exogenous $\mathrm{Fe}^{3+}$. The $\mathrm{Q}_{\max }$ values of the original peat and Fe-complexed peat were $2.83 \mathrm{mg} / \mathrm{g}$ and $7.36 \mathrm{mg} / \mathrm{g}$, respectively, while the $\mathrm{Q}_{\max }$ values of the original POM and Fe-POM associations were 4.31 $\mathrm{mg} / \mathrm{g}$ and $5.89 \mathrm{mg} / \mathrm{g}$, respectively. Based on the fact above, we confirmed that the contribution of Fe-OM associations to phosphorus removal in peatlands is much higher than that of inorganic iron oxide. However, the $\mathrm{Fe}-\mathrm{OM}$ associations can not fully explain the strong promoting effect of exogenous $\mathrm{Fe}^{3+}$ on phosphorus removal by peat soils, implying other coexisting removal mechanisms in iron-containing peat soils.

\section{Declarations}

\section{Compliance with ethical standards}

\section{Conflict of interest}

The authors declare that there is no conflict of interest.

\section{Acknowledgements}

The authors are thankful to the constructive comments and suggestions of anonymous reviewers and journal editors for editorial handing.

Funding This work was jointly supported by National Natural Science Foundation of China(NSFC 41977263 and 41472316), and Open Project of Technology Innovation Center for Ecological Evaluation 
and Remediation of Agricultural Land in plain area, MNR (Grant No. ZJGCJ202002)

Authors' contributions Weilin Yang: conceptualization, methodology, analysis, Writing-Original Draft. Wu Xiang: conceptualization, resources, writing - review \& editing. Ming Ma: Synthesis of different materials. Chunlei Huang, Xinzhe Lu and Yong Wang: investigation. Lingyang Yao: analysis, investigation. Zhengyu Bao: supervision

Data availability The data sets supporting the results of this article are included within the article and its additional files.

Ethical approval and consent to participate

Not applicable.

Consent to publish

Not applicable.

\section{References}

1. Arai Y, Livi K (2013) Underassessed phosphorus fixation mechanisms in soil sand fraction. Geoderma 192:422-429. https://doi.org/10.1016/j.geoderma.2012.06.021

2. Axt J, Walbridge M (1999) Phosphate Removal Capacity of Palustrine Forested Wetlands and Adjacent Uplands in Virginia. Soil Sci Soc Am J 63. https://doi.org/10.2136/sssaj1999.6341019x

3. Baldock J, Beare M, Curtin D, Hawke B (2018) Stocks, composition and vulnerability to loss of soil organic carbon predicted using mid-infrared spectroscopy. Soil Res 56. https://doi.org/10.1071/SR17221

4. Beare MH, Gregorich E (2007) Physically Uncomplexed Organic Matter. Soil Sampl. Methods Anal. https://doi.org/10.1201/9781420005271.ch47

5. Bohn H, McNeal B, O’Connor G (2014) Soil Chem Soil Sci 129:389. https://doi.org/10.1097/00010694-198006000-00010

6. Borggaard O, JDRGENSEN S, RABEN-LANGE MOBERGJ, B (2006) Influence of organic matter on phosphate adsorption by aluminium and iron oxides in sandy soils. J Soil Sci 41:443-449. https://doi.org/10.1111/j.1365-2389.1990.tb00078.x

7. Borggaard O, Raben-Lange B, Gimsing A, Strobel BW (2005) Influence of humic substances on phosphate adsorption by aluminium and iron oxides. Geoderma 127:270-279. https://doi.org/10.1016/j.geoderma.2004.12.011

8. Bruland G, Richardson C (2006) An Assessment of the Phosphorus Retention Capacity of Wetlands in the Painter Creek Watershed, Minnesota, USA. Water Air Soil Pollut 171:169-184. https://doi.org/10.1007/s11270-005-9032-7 
9. Chen K-Y, Chen T-Y, Chan Y-T, Cheng C-Y, Tzou Y, Liu Y-T, Teah H (2016) Stabilization of Natural Organic Matter by Short-Range-Order Fe Hydroxides. Environ Sci Technol 50.

https://doi.org/10.1021/acs.est.6b02793

10. Chen K-Y, Hsu L-C, Chan Y-T, Cho Y-L, Tsao F-Y, Tzou Y, Hsieh Y-C, Liu Y-T (2018) Phosphate Removal in Relation to Structural Development of Humic Acid-Iron Coprecipitates. Sci Rep 8:10363. https://doi.org/10.1038/s41598-018-28568-7

11. Cismasu A, Michel F, Tcaciuc AP, Tyliszczak T (2011) Composition and structural aspects of naturally occurring ferrihydrite. Comptes Rendus Geosci 343:210-218.

https://doi.org/10.1016/j.crte.2010.11.001

12. Cornell RM, SCHWERTMANN U (1979) Influence of Organic Anions on the Crystallization of Ferrihydrite. CLAYS CLAY MINER 27:402-410. https://doi.org/10.1346/CCMN.1979.0270602

13. Curti L, Moore OW, Babakhani P, Xiao K-Q, Woulds C, Bray AW, Fisher BJ, Kazemian M, Kaulich B, Peacock CL (2021) Carboxyl-richness controls organic carbon preservation during coprecipitation with iron (oxyhydr)oxides in the natural environment. Commun. EARTH Environ. 2. https://doi.org/10.1038/s43247-021-00301-9

14. Curtinrich HJ, Sebestyen SD, Griffiths NA, Hall SJ n.d. Warming Stimulates Iron-Mediated Carbon and Nutrient Cycling in Mineral-Poor Peatlands. ECOSYSTEMS. https://doi.org/10.1007/s10021-02100639-3

15. Deng Y, Weng L, Li Y, Ma J, Chen Y (2019) Understanding major NOM properties controlling its interactions with phosphorus and arsenic at goethite-water interface. Water Res 157. https://doi.org/10.1016/j.watres.2019.03.077

16. Dierberg F, DeBusk T, Kharbanda M, Potts J, Grace K, Jerauld M, Ivanoff D (2020) Long-term sustainable phosphorus $(P)$ retention in a low-P stormwater wetland for Everglades restoration. Sci Total Environ 756:143386. https://doi.org/10.1016/j.scitotenv.2020.143386

17. Dodds W, Smith VH (2016) Nitrogen, phosphorus, and eutrophication in streams. Inland water 6:155-164. https://doi.org/10.5268/IW-6.2.909

18. Dorau K, Pohl L, Just C, Hoeschen C, Ufer K, Mansfeldt T, Mueller C (2019) Soil Organic Matter and Phosphate Sorption on Natural and Synthetic Fe Oxides under in Situ Conditions. Environ. Sci. Technol. 2019. https://doi.org/10.1021/acs.est.9b03260

19. Elfarissi F, Pefferkorn E (2000) Kaolinite/humic acid interaction in the presence of aluminium ion. Colloids Surf A-physicochemical Eng Asp 168:1-12. https://doi.org/10.1016/S0927-7757(99)002927

20. Elliott E, Cambardella C (1991) Physical separation of soil organic matter. Agric Ecosyst Environ 34:407-419. https://doi.org/10.1016/0167-8809(91)90124-G

21. Eusterhues K, Hädrich A, Neidhardt J, Küsel K, Keller T, Jandt K, Totsche K (2014) Reduction of ferrihydrite with adsorbed and coprecipitated organic matter: Microbial reduction by Geobacter bremensis vs. abiotic reduction by Na-dithionite. Biogeosciences 11. https://doi.org/10.5194/bgd-116039-2014 
22. Fan Y, Wu Q, Bao B, Cao Y, Zhang S, Cui H (2021) Ferrihydrite reduces the bioavailability of copper and cadmium and phosphorus release risk in hydroxyapatite amended soil. J Environ Chem Eng 9. https://doi.org/10.1016/j.jece.2021.106756

23. Fu H, Quan X (2006) Complexes of fulvic acid on the surface of hematite, goethite, and akaganeite: FTIR observation. Chemosphere 63:403-410. https://doi.org/10.1016/j.chemosphere.2005.08.054

24. Gerke J, Hermann R (1992) Adsorption of Orthophosphate to Humic-Fe-Complexes and to Amorphous Fe-Oxide. Z für Pflanzenernährung und Bodenkd 155:233-236.

https://doi.org/10.1002/jpln.19921550313

25. Ghodsi V, Sarathy S, Walton J, Watson I, Elbeshbishy E, D., S (2020) Enhancing sludge dewaterability and phosphate removal through a novel chemical dosing strategy using ferric chloride and hydrogen peroxide. Water Environ Res 93. https://doi.org/10.1002/wer.1395

26. Green-Pedersen H, Pind N (2000) Preparation, characterization, and sorption properties for Ni(II) of iron oxyhydroxide-montmorillonite. Colloids Surf Physicochem Eng Asp 168:133-145. https://doi.org/10.1016/S0927-7757(00)00448-9

27. Gregorich E, Beare M, McKim U, Skjemstad J (2006) Chemical and Biological Characteristics of Physically Uncomplexed Organic Matter. Soil Sci Soc Am J 70. https://doi.org/10.2136/sssaj2005.0116

28. Haritash AK, Dutta S, Sharma A (2017) Phosphate uptake and translocation in a tropical Cannabased constructed wetland. Ecol Process 6. https://doi.org/10.1186/s13717-017-0079-3

29. Hayes MHB, Senesi N, Xing B, Huang PM (2009) Evolution of concepts of environmental natural nonliving organic matter, biophysico-chemical processes involving natural nonliving organic matter in environmental systems. Wiley-IUPAC Ser Biophys Process Environ Syst 1-39. https://doi.org/10.1002/9780470494950

30. Kaiser K, Guggenberger G (2003) Mineral surfaces and soil organic matter. Eur J Soil Sci 54:219236. https://doi.org/10.1046/j.1365-2389.2003.00544.x

31. Kang J, Hesterberg D, Osmond D (2009) Soil Organic Matter Effects on Phosphorus Sorption: A Path Analysis. Soil Sci Soc Am J 73. https://doi.org/10.2136/sssaj2008.0113

32. Khouri E, Barrón V, Torrent J (1995) Organic Matter Delays But Does Not Prevent Phosphate Sorption By Cerrado Soils From Brazil. Soil Sci 159. https://doi.org/10.1097/00010694-199515930-00008

33. Kleber M, Eusterhues K, Keiluweit M, Mikutta C, Mikutta R, Nico PS (2015) Chapter One - MineralOrganic Associations: Formation, Properties, and Relevance in Soil Environments, in: Sparks, D.L. (Ed.), Advances in Agronomy. Academic Press, pp. 1-140. https://doi.org/https://doi.org/10.1016/bs.agron.2014.10.005

34. Koivula N, Hänninen K (2001) Concentrations of monosaccharides in humic substances in the early stages of humification. Chemosphere 44:271-279. https://doi.org/10.1016/S0045-6535(00)00167-3

35. Koopmans GF, Hiemstra T, Vaseur C, Chardon WJ, Voegelin A, Groenenberg J (2019) Use of iron oxide nanoparticles for immobilizing phosphorus in-situ: Increase in soil reactive surface area and 
effect on soluble phosphorus. Sci Total Environ 711:135220.

https://doi.org/10.1016/j.scitotenv.2019.135220

36. Kubicki J, Kristian W, Kabalan L, Zhu Q, Mrozik M, Aryanpour M, Pierre-Louis A-M, Strongin D (2012) ATR-FTIR and Density Functional Theory Study of the Structures, Energetics, and Vibrational Spectra of Phosphate Adsorbed onto Goethite. Langmuir 28:14573-14587.

https://doi.org/10.1021/la303111a

37. Laird D (2001) Nature of Clay-Humic Complexes in an Agricultural Soil. Soil Sci Soc Am J 65. https://doi.org/10.2136/sssaj2001.6551419x

38. Lalonde K, Mucci A, Ouellet A, Gelinas Y (2012) Preservation of organic matter in sediments promoted by iron. Nature 483:198-200. https://doi.org/10.1038/nature10855

39. Li J, Ding Y, Wang K, Li N, Guangren Q, Xu Y, Zhang J (2019) Comparison of humic and fulvic acid on remediation of arsenic contaminated soil by electrokinetic technology. Chemosphere 241:125038. https://doi.org/10.1016/j.chemosphere.2019.125038

40. Li X, Fan Q, Yang Y-L (2008) Efficiency and mechanism of trace phosphorus removal in water by ironaluminum composited adsorbent. J Beijing Univ Technol 34:310-313

41. Liu W-T, Linning K, Nakamura K, Mino T, Matsuo T, Forney L (2000) Microbial community changes in biological phosphate-removal systems on altering sludge phosphorus content. Microbiology 146(Pt 5):1099-1107. https://doi.org/10.1099/00221287-146-5-1099

42. Liu J, Zhu R, Ma L, Fu H, Lin X, Parker SC, Molinari M (2021) Adsorption of phosphate and cadmium on iron (oxyhydr)oxides: A comparative study on ferrihydrite, goethite, and hematite. Geoderma 383. https://doi.org/10.1016/j.geoderma.2020.114799

43. López P, Lluch X, Vidal M, Morguí J (1996) Adsorption of Phosphorus on Sediments of the Balearic (Spain) Related to Their Composition. Estuar Coast Shelf Sci 42:185-196. https://doi.org/10.1006/ecss.1996.0014

44. Mazzetti L, Thistlethwaite PJ (2002) Raman spectra and thermal transformations of ferrihydrite and schwertmannite. J Raman Spectrosc 33:104-111. https://doi.org/10.1002/jrs.830

45. Meinikmann K, Hupfer M, Lewandowski J (2015) Phosphorus in groundwater discharge - A potential source for lake eutrophication. J Hydrol 524. https://doi.org/10.1016/j.jhydrol.2015.02.031

46. Mikutta R, Kleber M, Torn M, Jahn R (2006) Stabilization of Soil Organic Matter: Association with Minerals or Chemical Recalcitrance? Biogeochemistry 77:25-56. https://doi.org/10.1007/s10533005-0712-6

47. Mikutta R, Mikutta C, Kalbitz K, Scheel T, Kaiser K, Jahn R (2007) Biodegradation of Forest Floor Organic Matter Bound to Minerals via Different Binding Mechanisms. Geochim Cosmochim Acta 71:2569-2590. https://doi.org/10.1016/j.gca.2007.03.002

48. Morris A, Hesterberg D (2012) Iron(III) Coordination and Phosphate Sorption in Peat Reacted with Ferric or Ferrous Iron. Soil Sci Soc Am J 76:101. https://doi.org/10.2136/sssaj2011.0097

49. Murphy J, Riley JP (1962) A Modified Single Solution Method for the Dermination of Phosphate in Natural Waters. Anal Chim Acta 26:678-681 
50. Newcomb C (2015) Humic Matter in Soil and the Environment, Principles and Controversies. Soil Sci Soc Am J 79:1520. https://doi.org/10.2136/sssaj2015.0004br

51. Ni Z, Wang S, Wu Y, Liu X, Lin R, Liu Z (2020) Influence of exposure time on phosphorus composition and bioavailability in wetland sediments from Poyang lake, since the operation of the Three Gorges Dam. Environ Pollut 263:114591. https://doi.org/10.1016/j.envpol.2020.114591

52. Nur R, Bates MH (1979) The effects of $\mathrm{pH}$ on the aluminum, iron and calcium phosphate fractions of lake sediments. Water Res 13:813-815. https://doi.org/https://doi.org/10.1016/00431354(79)90247-1

53. Ohno T, Kubicki J (2020) Adsorption of Organic Acids and Phosphate to an Iron (Oxyhydr)oxide Mineral: A Combined Experimental and Density Functional Theory Study. J Phys Chem A XXXX. https://doi.org/10.1021/acs.jpca.9b12044

54. Page S, Rieley J, Banks C (2010) Global and regional importance of the tropical peatland carbon pool. Glob Chang Biol 17. https://doi.org/10.1111/j.1365-2486.2010.02279.x

55. Parfitt R (1982) Competitive adsorption of phosphate and sulphate on goethite (alpha $-\mathrm{FeOOOH})$ : a note. New Zeal J Sci 25:147-148

56. Piccolo A, Martino A, Scognamiglio F, Ricci R, Spaccini R (2021) Efficient simultaneous removal of heavy metals and polychlorobiphenyls from a polluted industrial site by washing the soil with natural humic surfactants. Environ Sci Pollut Res. https://doi.org/10.1007/s11356-021-12484-x

57. Rodionov A, Amelung W, Urusevskaja I, Zech W (2000) Carbon and nitrogen in the enriched labile fraction along a climosequence of zonal steppe soils in Russia. Soil Sci Soc Am J 64:1467-1473. https://doi.org/10.2136/sssaj2000.6441467x

58. Schwertmann VU, Cornell RM, Von U (1992)und R. M. Cornell. Angewandte Chemie, 104(11),15691569. http://doi.wiley.com/10.1002/ange.19921041155

59. Shao X, Zhang YS, Lin X-Y, Du ST, Yu CY (2006) Phosphorus adsorption and desorption properties of three synthetic iron oxides and their relation to phosphorus adsorption saturation. Plant Nutr Fertil Sci 12:208-212

60. Six J, Guggenberger G, Paustian K, Haumaier L, Elliott E, Zech W (2002) Sources and composition of soil organic matter fractions between and within aggregates. Eur J Soil Sci 52:607-618. https://doi.org/10.1046/j.1365-2389.2001.00406.x

61. Six J, Merckx R, Kimpe K, Paustian K, Elliott E (2008) A re-evaluation of the enriched labile soil organic matter fraction. Eur J Soil Sci 51:283-293. https://doi.org/10.1046/j.13652389.2000.00304.x

62. Song K, Zoh K-D, Kang H (2007) Release of phosphate in a wetland by changes in hydrological regime. Science of the Total Environment, 380, 13-18. Sci. Total Environ. 380, 13-18. https://doi.org/10.1016/j.scitotenv.2006.11.035

63. Spangler J, Sample D, Fox L, Albano J, White S (2019) Assessing nitrogen and phosphorus removal potential of five plant species in floating treatment wetlands receiving simulated nursery runoff. Environ Sci Pollut Res 26. https://doi.org/10.1007/s11356-018-3964-0 
64. Swift RS (1996) Organic matter characterization. In Methods of Soil Analysis. Part 3. Chemical Methods., Sparks, D. L.; Page, A. L.; Helmke, P. A.; Loeppert, R. H., Soltanpour, P. N.; Tabatabai, M. A.; Johnston, C. T.; Sumner, M. E., Eds.; Soil Science Society of America: Madison; pp1011-1069

65. Tan WF, Zhou SZ, Liu F, Feng XH, Li XY (2007) Advancement in the Study on Interactions between Iron-aluminum (Hydro-) Oxides and Clay Minerals in Soil (in Chinese). Soils 39(5):726-730

66. Thomasarrigo L, Byrne J, Kappler A, Kretzschmar R (2018) Impact of Organic Matter on Iron(II)Catalyzed Mineral Transformations in Ferrihydrite-Organic Matter Coprecipitates. Environ Sci Technol 52. https://doi.org/10.1021/acs.est.8b03206

67. Thomasarrigo L, Kaegi R, Kretzschmar R (2019) Ferrihydrite Growth and Transformation in the Presence of Ferrous Iron and Model Organic Ligands. Environ Sci Technol 53. https://doi.org/10.1021/acs.est.9b03952

68. Vandevoort A, Arai Y (2011) Role of Natural Nanoparticles in Phosphorus Transport Processes in Ultisols. Soil Sci Soc Am J 75:335. https://doi.org/10.2136/sssaj2010.0124nps

69. Violante A, Huang P (1989) Influence of Oxidation Treatments on Surface Properties and Reactivities of Short-Range Ordered Precipitation Products of Aluminum. Soil Sci Soc Am J 53:1402. https://doi.org/10.2136/sssaj1989.03615995005300050016x

70. Wang H, Zhu J, Fu Q, Hu H (2015a) Adsorption of phosphate on pure and humic acid-coated ferrihydrite. J Soils Sediments 15. https://doi.org/10.1007/s11368-015-1095-5

71. Wang H, Zhu J, Fu Q-L, Xiong J-W, Hong C, Hu H, Violante A (2015b) Adsorption of Phosphate onto Ferrihydrite and Ferrihydrite-Humic Acid Complexes. https://doi.org/10.1016/S1002-0160(15)300084. Pedosphere 25

72. Wang J, Li H, Tang L, Zhong C, Liu Y, Lu L, Qiu T, Liu H (2020) Behavior and mechanism of lowconcentration rare earth ions precipitated by the microbial humic-like acids. Environ Sci Pollut Res 27. https://doi.org/10.1007/s11356-020-08521-w

73. Wang X, Liu F, Tan W, Li W, Feng X, Sparks D (2013) Characteristics of Phosphate AdsorptionDesorption Onto Ferrihydrite: Comparison With Well-Crystalline Fe (Hydr)Oxides. Soil Sci 178:1-11. https://doi.org/10.1097/SS.0b013e31828683f8

74. Wang Y, Wang H, He J-S, Feng X (2017) Iron-mediated soil carbon response to water-table decline in an alpine wetland. Nat Commun 8:15972. https://doi.org/10.1038/ncomms15972

75. Wen QX (1984) research method of soil organic matter(In Chinese)

76. Weng L, Riemsdijk W, Hiemstra T (2009) Humic Nanoparticles at the Oxide-Water Interface: Interactions with Phosphate Ion Adsorption. Environ Sci Technol 42:8747-8752. https://doi.org/10.1021/es801631d

77. Wu H, Button M, Konnerup D, Brix H (2019) Impact of engineered nanoparticles on microbial transformations of carbon, nitrogen, and phosphorus in wastewater treatment processes - A review. Sci Total Environ 660. https://doi.org/10.1016/j.scitotenv.2019.01.106

78. Yang YL, Li X, Fan Q (2009a) Preparation of iron-aluminum composited adsorbent and the removal trace phosphorus. Trans Beijing Inst Technol 29:73-75 
79. Yang Y-L, Xing L, Can-Xiong G, Zhao F-W, Feng J (2009b) Efficiency and Mechanism of Phosphorus Removal by Coagulation of Iron-manganese Composited Oxide.J. Beijing Univ. Technol.35

80. YONEBAYASHI K (2006) Studies on sustainable land use and soil ecosystems in tropical peat land. Tropics 15:313-320. https://doi.org/10.3759/tropics.15.313

81. Yuhui M, Dai W, Zheng P, Zheng X, He S, Zhao M (2020) Iron scraps enhance simultaneous nitrogen and phosphorus removal in subsurface flow constructed wetlands. J Hazard Mater 395:122612. https://doi.org/10.1016/j.jhazmat.2020.122612

82. Zaccone C, Cocozza C, Cheburkin AK, Shotyk W, Miano TM (2007) Enrichment and depletion of major and trace elements, and radionuclides in ombrotrophic raw peat and corresponding humic acids. Geoderma 141:235-246. https://doi.org/https://doi.org/10.1016/j.geoderma.2007.06.007

83. Zak D, Roth C, Unger V, Goldhammer T, Fenner N, Freeman C, Jurasinski G (2019) Unraveling the Importance of Polyphenols for Microbial Carbon Mineralization in Rewetted Riparian Peatlands. Front Environ Sci 7:147. https://doi.org/10.3389/fenvs.2019.00147

84. Zhao Y, Xiang W, Ma M, Zhang X, Bao Z, Xie S, Yan S (2019) The role of laccase in stabilization of soil organic matter by iron in various plant-dominated peatlands: degradation or sequestration? https://doi.org/10.1007/s11104-019-04245-0. Plant Soil 443

85. Zhao Y, Xiang W, Zhang X, Xie S, Yan S, Wu C, Liu Y (2020) Mechanistic study on laccase-mediated formation of Fe-OM associations in peatlands. Geoderma 375:114502. https://doi.org/10.1016/j.geoderma.2020.114502

86. Zhao Y, Xiang W, Huang C, Liu Y, Tan Y (2021) Production of hydroxyl radicals following water-level drawdown in peatlands: A new induction mechanism for enhancing laccase activity in carbon cycling. SOIL Biol Biochem 156. https://doi.org/10.1016/j.soilbio.2021.108241

87. Zhou Y, Zhang Y, Li P, Li G (2014) Comparative study on the adsorption interactions of humic acid onto natural magnetite, hematite and quartz: Effect of initial HA concentration. Powder Technol 251:1-8. https://doi.org/10.1016/j.powtec.2013.10.011

\section{Figures}

\section{Figure 1}

SEM patterns of iron oxides and Fe-HS associations

\section{Figure 2}

XRD patterns of iron oxides and Fe-HS associations 


\section{Figure 3}

FTIR spectra of HA and FA

\section{Figure 4}

Adsorption isotherms of phosphate onto goethite, hematite, ferrihydrite and four types of Fe-HS associations using the Langmuir model

\section{Figure 5}

Adsorption isotherms of phosphate by POM with different concentrations of $\mathrm{Fe}^{3+}$ solution using the Langmuir model

\section{Figure 6}

Adsorption isotherms of phosphate onto Fe-complexed peat soils with different concentrations of added $\mathrm{Fe}^{3+}$ using the Langmuir model

\section{Figure 7}

Comparison between the theoretical predicted value of $\mathrm{Q}_{\max }$ caused by Ferrihydrite and Hematite and the actual increased $Q_{\max }$ 